\title{
In vitro protocol optimization for development of interspecific hybrids of oil palm (Elaeis oleifera (H.B.K) Cortés x Elaeis guineensis Jacq.)
}

\author{
Sergio Augusto Oliveira Alves ${ }^{1 *}$, Oriel Filgueira de Lemos ${ }^{2}$, Benedito Gomes dos Santos \\ Filho ${ }^{3}$ and André Luís Lopes da Silva ${ }^{4}$
}

${ }^{1}$ Departamento de Ciências florestais e Laboratório de Recursos Genéticos e Biotecnologia; Escola Superior de Agricultura Luiz de Queiroz - ESALQ/USP; 13418-900; Piracicaba - SP - Brasil. ${ }^{2}$ Embrapa Amazônia Oriental ,Pavilhão de Pesquisa; 66095-100 ; Belém - PA - Brasil. ${ }^{3}$ Universidade Federal Rural da Amazônia -UFRa ;Departamento de Fisiologia Vegetal; 66077-901; Belém - PA - Brasil. ${ }^{4}$ Departamento de Engenharia de Bioprocessos e Biotecnologia; Universidade Federal do Paraná; 81531-970; Curitiba - PR - Brasil.

\begin{abstract}
The oil palm (Elaeis guineensis) is the major source of plant oil in the world. Nevertheless, is susceptible to the fatal yellowing disease, which is affecting the oil palm production in Pará state, Brazil. To overcome this problem, interspecific hybrids of Elaeis oleifera $x$ Elaeis guineensis is a viable alternative. Some protocols for in vitro embryo rescue were already established, but it is necessary to optimize it. The aim of this paper was to optimize the in vitro protocol for culture of embryos from interspecific hybrids of oil palm (E. oleifera $x$ E. guineensis). Disinfection embryos were carried out with 1 and $2 \% \mathrm{NaOCl}$ for 20 or 40 minutes. Embryos were germinated in vitro on the presence of 0, 0.1, 0.2 and 0.25\% activated charcoal and Embryos were cultured in vitro on the presence of 2.4Dichlorophenoxyacetic acid (2.4-D) at 375, 500 and $625 \mu M$ for callus induction. Activated charcoal (0.25\%) is necessary to reduce oxidation in the embryos. Seed disinfection can be suitable reached with $1 \% \mathrm{NaOCl}$ for 20 minutes. Different varieties have different ideal levels of 2.4-D for callus induction. The best level of 2.4-D for callus induction is 375 and $625 \mu M$ for the varieties SJ-167 and SJ-165, respectively.
\end{abstract}

Key words: Activated charcoal, phenolic oxidation, embryo rescue, callogenesis

\section{INTRODUCTION}

The oil palm (Elaeis guineensis jacq.) belongs to Arecaceae family. It is native of the West Africa. In Brazil, its dispersion happened in the century $\mathrm{XV}$ through the slaves' traffic. This species is the major source of plant oil in the world, nevertheless is susceptible to the fatal yellowing disease (Alves et al., 2011). On the other hand, the caiaue (Elaeis oleifera (HBK) Cortés) is native from Brazil, more specifically of the Amazon region, and the main characteristics is low yield, high quality of oil and tolerance about some diseases, especially against fatal yellowing disease. Nowadays, in Brazil, the Pará state is a major producer of oil palm with about 220160.000 ton per year (Alves, 2007). Nevertheless, in the last years, fatal yellowing disease is becoming a barrier to the development of oil palm plantation. The main symptom of this disease is a yellowish at the basal of youngest leaves, which causes the plant death in few period of time, and its etiologic agent is unknown.

The obtaining of interspecific hybrids between $E$. oleifera and E.guineensis can be an alternative viable to overcome the problem of the fatal yellowing disease. Despite being geographically isolated, these two species are cross-compatible and fertile hybrids can be easily obtained (Hardon and Tan 1969; Amblard et al., 1995). However, these interspecific hybrids $(E$. oleifera $\mathrm{x} E$. guineensis) have a problem with regard to the development of embryo, resulting sometimes in seed abortion (Viegas and Muller, 2000). Nevertheless, tissue culture can overcome this problem with regard to the development of the embryo; these embryos can be rescued before to be aborted. Moreover, the possibility for the

Author for correspondence: sergioagrobio@ig.com.br 
propagation in wide scale using tissue culture is the main alternative to the development of interspecific hybrids (E. oleifera x E. guineensis) in areas affected by fatal yellowing disease (Teixeira et al., 1993; Alves, 2007). Therefore, the aim of this paper was to optimize the in vitro protocol for culture of embryos from interspecific hybrids of oil palm (E. oleifera x E. guineensis).

\section{MATERIAL AND METHODS \\ Plant Material}

The experiments were carried out at laboratory of Biotechnology and Genetic Resources of Embrapa-Amazonia Oriental, Pará, Brazil. It was used seeds originated from crosses between (Elaeis oleifera $\mathrm{x}$ Elaeis guineensis) from Germplasm bank of Embrapa - Amazonia ocidental, Manaus, Brazil. In order to establish the disinfection and oxidation tests were used the variety SJ-165. In order to induce calli were used the varieties SJ-165 and SJ -167 .

\section{Embryos cultured in different levels of activated charcoal}

The disinfection of the embryos was accomplished in agreement with the protocol established by Alves et al. (2011). The embryos was excised of the seeds and transferred immediately to flask culture with $50 \mathrm{ml}$ of culture medium containing a half strength MS medium (Murashige and Skoog, $1962)$ added with sucrose (3\%). The treatments consisted of: $0,0.1,0.2$ and $0.25 \%$ of activated charcoal. In the first week, the embryos were cultivated in the dark. The length stem and root number of germinated embryos was evaluated after 30 days of in vitro culture.

\section{Embryos disinfection}

The seeds were washed with distilled and sterile water for five times until do not exist any type of visible dirt. After this washing, the seeds were placed in a laminar air flow chamber followed by immersion in 70\% alcohol for 2 minutes and after, followed to the treatments: 1 and $2 \% \mathrm{NaOCl}$ for 20 or 40 minutes, and after this immersion the embryos were washed for four times with distilled and sterile water. After the disinfection the embryos were removed from seeds and inoculated on the germination medium. The germination medium was composed with MS medium supplemented with sucrose (3\%) and activated charcoal $(0.25 \%)$. In the first week, the embryos were cultivated in the dark. The percentage of contamination and number of the embryos germinated was evaluated after 30 days of in vitro culture.

\section{Callus induction}

The sterilized embryos of the varieties (SJ-165) and (SJ-167) were inoculated within flask culture containing $25 \mathrm{ml}$ of basal medium, which was constituted with: 1/2 MS medium, added with sucrose $(3 \%)$ and activated charcoal $(0.25 \%)$. The treatments were: 375,500 and $625 \mu \mathrm{M}$ 2.4-D for both varieties. The cultures were incubated in the dark for 12 weeks. Each 30 days the calli were subcultured in the same medium during this period.

\section{Statistical analysis and culture conditions}

The experimental design was completely randomized with twelve replicates of three embryos. The data was submitted to the normality analysis (Lilliefors's test) and, analysis of variance (ANOVA) followed by regression analysis (data from quantitative treatments) or Tukey's test (data from qualitative treatments), both at a $\mathrm{P}<0.05$. All statistical analyses were done following the procedures of the software BIOSTAT 3.0 (from Federal University of Pará). Variables from counting were transformed to $\sqrt{x+0.5}$ and variables from percentage were transformed to $\arcsin \sqrt{x / 100}$.

All the mediums were solidified with $0.2 \%$ phytagel. The $\mathrm{pH}$ of all medium was adjusted to 5.8 with $0.1 \mathrm{NaOH}$ or $\mathrm{HCl}$ before phytagel was added. The medium were autoclaved at $121^{\circ} \mathrm{C}$ for 15 min. Cultures were maintained in growth chamber at $27 \pm 2^{\circ} \mathrm{C}$ and photoperiod of 16 hours under a light intensity of $25 \mu \mathrm{M} \cdot \mathrm{m}^{-2} \cdot \mathrm{S}^{-1}$ obtained with white fluorescent lamps.

\section{RESULTS AND DISCUSSION}

Embryos cultured in different levels of activated charcoal

Independently of the concentration of activated charcoal used, it was observed significant influence on the results obtained. The embryos cultured in presence of activated charcoal showed a better development in the length stem and root number (Table 1). 
Table 1. Effect of activated charcoal in culture medium containing half strength of Murashige and Skoog (1/2 MS) on length of stem and root number in interspecific hybrids of oil palm (Elaeis guineensis x Elaeis oleifera).

\begin{tabular}{ccc}
\hline Culture medium & Length of stem $(\mathbf{c m})$ & Number of root \\
\hline With charcoal & $3.7 \mathrm{a}$ & $2.4 \mathrm{a}$ \\
Without charcoal & $1.7 \mathrm{~b}$ & $1.7 \mathrm{~b}$ \\
\hline CV\% & 15.4 & 8.7
\end{tabular}

Means followed by the same letter in columns are not significant by Tukey's test $(p<0.05)$.

Perennials plants such as oil palm are rich in substances originated of the secondary metabolism, such as polyphenolic compounds and when these substances are in in vitro culture, tissues suffer oxidation due to polyphenolic oxidase enzyme and to avoid this process, is necessary some substance such as activated charcoal, that removes these compounds in culture medium (Cattelan et al., 2007; Alves, 2007). The activated charcoal can adsorb phenolic compounds and their products of oxidation, such as quinones, avoiding the oxidation process. (Teixeira et al., 1993; Alves, 2007).

In the regression analyses (Figure 1), it was observed a negative linear effect, and when the activated charcoal concentration increases, the percentage of oxidation decreases, being the minor percentage of embryos with oxidation found in $0.25 \%$ activated charcoal. Similar results were obtained with açaí palm (Euterpe oleraceae using $0.2 \%$ of activated charcoal that there was suitanable reduction in oxidation process (Cavalcante, 2001).

Activated charcoal in medium eliminates undesirable compounds, which aid to promote the normal development the plant in vitro, mainly in the first stages of growth (Freitas et al., 2009; Souza et al., 2009). Nevertheless, the increase of activated charcoal level into culture medium can be prejudicial, because the higher concentration could adsorb other substances of the culture medium, such as growth regulators, what could lead the undesired effects to the in vitro culture (Teixeira et al., 1993; Pullman et al., 2005; Alves, 2007).

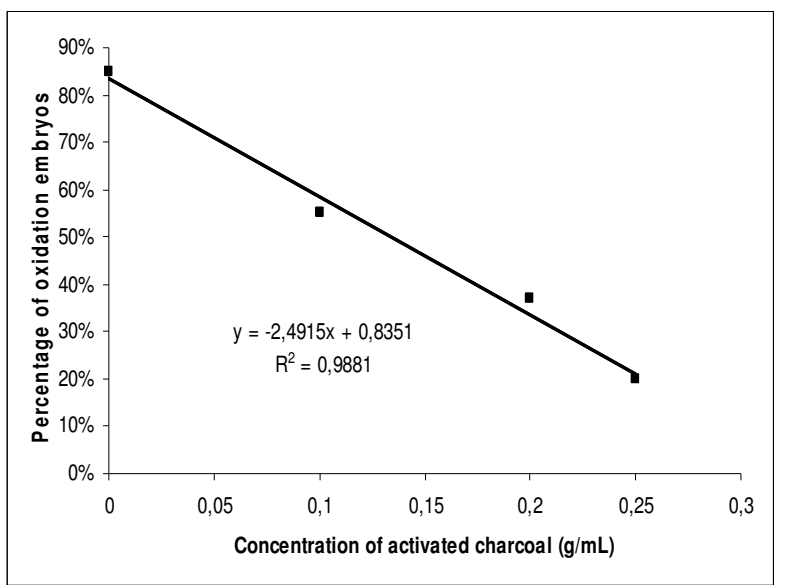

Figure 1 - Effect of Different concentrations of activated charcoal on percentage of oxidation of oil palm embryos (Elaeis guineensis x Elaeis oleifera) after 30 days of culture.

\section{Embryos disinfection}

In the disinfection of the oil palm seeds, the contamination rate varied from 22 to $28 \%$ and there are not statistical differences among the treatments (Figure 2).

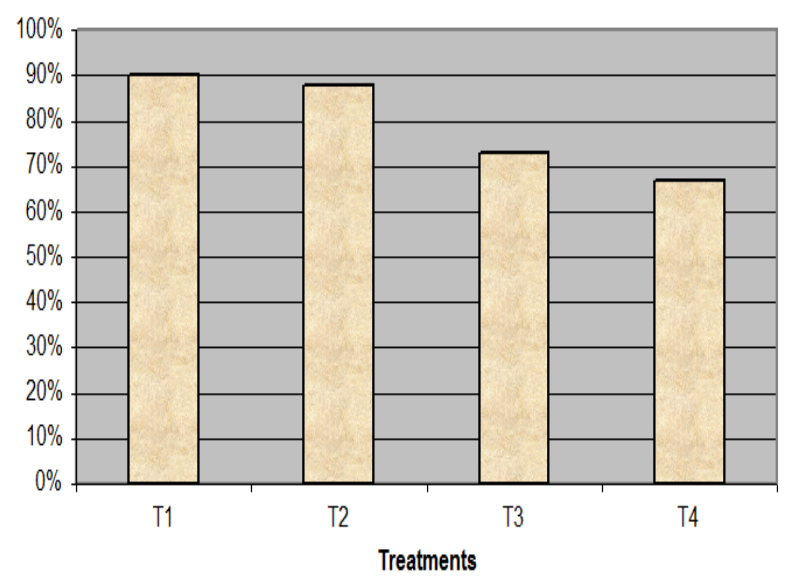

Figure 2 - Percentage of axenic embryos of oil palm (Elaeis oleifera $\mathrm{x}$ Elaeis guineensis) germinated in vitro under four different treatments (T1- 1\% NaClO for 20 minutes; $\mathrm{T} 2-1 \% \mathrm{NaClO}$ for 40 minutes; $\mathrm{T} 3-2 \%$ $\mathrm{NaClO}$ for 20 minutes; $\mathrm{T} 4-2 \% \mathrm{NaClO}$ for 40 minutes) after 30 days of culture. 
The embryos originated in the disinfection process varied from $67 \%$ to $90 \%$ of germination rate (Figure 2). The number of germinated embryos showed statistical differences in all treatments, varied from 0.88 to 1.18 .

Table 2. Effects the time and levels of sodium hypochlorite $(\mathrm{NaClO})$ in the disinfection of oil palm (Elaeis oleifera $\mathrm{x}$ Elaeis guineensis) seeds.

\begin{tabular}{cllll}
\hline Time & \multicolumn{2}{c}{ NaClO 1\% } & \multicolumn{2}{c}{ NaClO 2\% } \\
& Contamination\% & Not Contamination\% & Contamination\% & Not Contamination\% \\
\hline 20 minutes & $22(10) \mathrm{a}$ & $78(35) \mathrm{a}$ & $22(9) \mathrm{a}$ & $78(36) \mathrm{a}$ \\
40 minutes & $28(13) \mathrm{a}$ & $72(32) \mathrm{a}$ & $22(10) \mathrm{a}$ & $78(35) \mathrm{a}$ \\
\hline
\end{tabular}

Means followed by the same letter in columns are not significant by Tukey's test $(p<0.05)$.

For the number of embryos germinated the best results were $\mathrm{T}_{1}$ and $\mathrm{T}_{3}$ (Table 3 ). The time exposition of $\mathrm{NaOCl}$ is more harmful for embryos than the level. Similar results were found in murmuru (Astrocharyum ulei) which about $85.9 \%$ of germination of the zygotic embryos were obtained with the same concentration of sodium hypochlorite, however with minor exposition time which was 10 minutes (Pereira et al., 2006).

Table 3. Number of embryos of oil palm (Elaeis oleifera $\mathrm{x}$ Elaeis guineensis) germinated in four different treatments (T1- $1 \% \mathrm{NaClO}$ for 20 minutes; $\mathrm{T} 2-1 \% \mathrm{NaClO}$ for 40 minutes; $\mathrm{T} 3-2 \% \mathrm{NaClO}$ for 20 minutes; $\mathrm{T} 4-2 \% \mathrm{NaClO}$ for 40 minutes) after 30 days of culture.

\begin{tabular}{cc}
\hline Treatments & Means of germinated embryos \\
\hline T1 & $1.18 \mathrm{a}$ \\
T2 & $1.17 \mathrm{a}$ \\
T3 & $1.02 \mathrm{c}$ \\
T4 & $0.88 \mathrm{~d}$ \\
\hline
\end{tabular}

Means followed by the same letter in columns are not significant by Tukey's test $(p<0.05)$. CV\% $=10.25$

\section{Callus Induction}

Callus initiation was observed within 4-6 weeks after inoculation of the embryos in medium for callus induction. In generally, the calli showed two patterns; white pattern and another with yellow appearance (Figure 3).

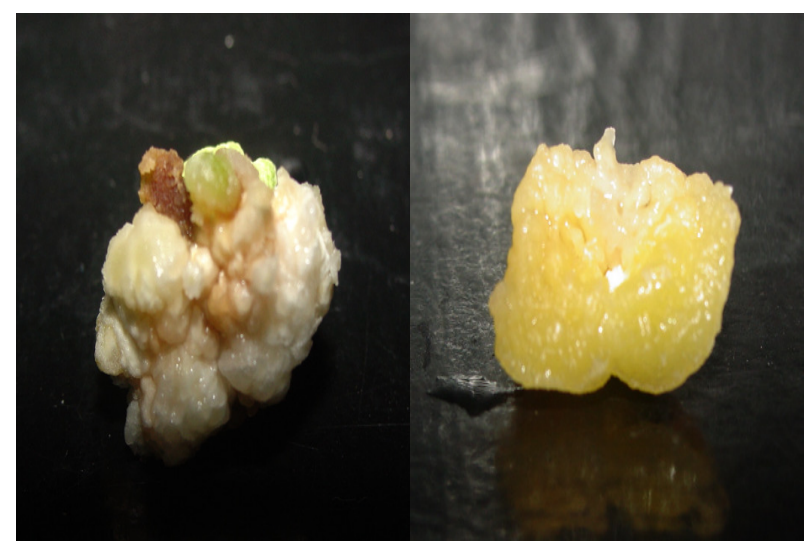

Figure 3 - Two different patterns of callus formed. The first callus shows the white pattern and the second the yellow appearance pattern.
The two varieties showed different responses in in vitro culture. For the variety (SJ-165) in $1 / 2 \mathrm{MS}$ medium, the best percentage of embryogenic callus occurred in the culture medium supplemented with $625 \mu \mathrm{M}$ 2.4-D (30\%), followed of $500 \mu \mathrm{M}(11.60 \%)$ and $375 \mu \mathrm{M}$ 2.4-D with $3.0 \%$ only.

However, for the variety (SJ-167), the results were quite opposite to the SJ-165, the best level was $375 \mu \mathrm{M}$ 2.4-D which obtained $31.6 \%$ of calli, followed of $500 \mu \mathrm{M}(19.60 \%)$ and $625 \mu \mathrm{M}$ 2.4-D $(8.3 \%)$ (Figure 4).For the variety SJ-165, the increase of concentration of 2.4-D promotes higher calli rate. However, for the variety SJ-167; the increase of the levels of 2.4-D decreases the calli rate.

The culture of callus can result in shoots or somatic embryos; however, it is necessary the exogenous supplementation with plant growth regulators for the adequate adjust between auxins and citokinins (Nogueira et al., 2007; Santos et al., 2010). 


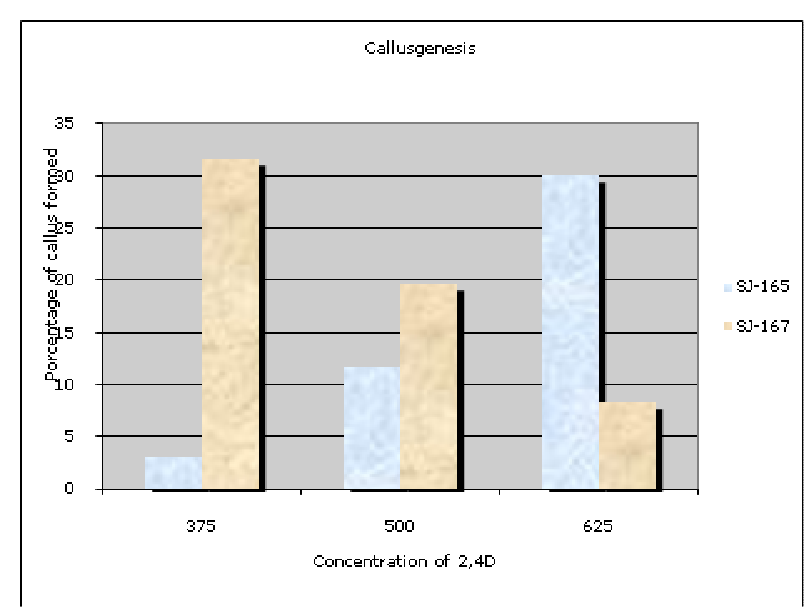

Figure 4 - Percentage of calli formed in different concentration of 2.4-D in the varieties SJ-165 and SJ167.

These differences between varieties, could reflect the genotype $\mathrm{x}$ environment interaction, that are the different responses obtained by genotypes in relation the same environmental conditions or when the same genotype responses differentially of accord with environment where itself find (Obisesan and Fatunla, 1983).

The tissue culture is an important tool in genetic breeding to identification of genotypes that show high phenotype stability, or in general, genotypes that had great adaptability, being able to produce in different media culture (Cruz and Regazzi, 1997).

In oil palm, callus was obtained with a minor concentration of 2.4-D $(113 \mu \mathrm{M})$ in culture medium free of activated charcoal, however, the absence of the activated charcoal increased the oxidation percentage. (Rajesh et al., 2003). In oil palm cultured with the presence of activated charcoal in the culture medium was necessary increases fifty times $(50 \mathrm{x})$ the $2.4-\mathrm{D}$ concentration to obtain the same result (Teixeira et al., 1993).

\section{CONCLUSION}

Activated charcoal $(0.25 \%)$ is necessary to reduce oxidation in the embryos. Seed disinfection can be suitable reached with $1 \% \mathrm{NaOCl}$ for 20 minutes. Different varieties have different ideal levels of 2.4-D for callus induction. The best level of 2.4-D for callus induction is 375 and $625 \mu \mathrm{M}$ for the varieties SJ-167 and SJ-165, respectively.

\section{RESUMO}

O dendezeiro (Elaeis guineensis) é a maior fonte de óleo vegetal no mundo. Porém, a doença do amarelecimento fatal está dizimando plantações no estado do Pará, Brasil. Para superar esse problema, híbridos interespecíficos de Elaeis oleifera x Elaeis guineensis são uma alternativa viável. Contudo alguns protocolos para o resgate in vitro desses embriões já foram estabelecidos, porém é necessário otimizá-los. O objetivo dessa pesquisa foi otimizar o protocolo in vitro para o cultivo de embriões interespecíficos de (Elaeis oleifera x Elaeis guineensis). A desinfestação das sementes foi realizada com 1 ou $2 \%$ de $\mathrm{NaOCl}$ por 20 ou 40 minutos. Embriões foram germinados in vitro na presença de $0 ; 0,1 ; 0,2$ e $0,25 \%$ de carvão ativado e embriões foram cultivados na presença do ácido 2,4diclorofenoxiacético (2,4-D) nas concentrações de 375, 500 e $625 \mu \mathrm{M}$ para a indução de calos. A adição de 2,5\% de carvão ativado é necessária para reduzir a oxidação fenólica dos embriões. A desinfestação das sementes pode ser realizada com $1 \%$ de $\mathrm{NaOCl}$ por 20 minutos. Diferentes variedades possuem diferentes concentrações ideais de 2,4-D para a indução de calos. As melhores concentrações de 2,4-D foram 375 e 625 $\mu \mathrm{M}$ para as variedades SJ-167 e SJ-165, respectivamente.

Palavras-chave: Carvão ativado, oxidação fenólica, resgate de embriões, calogênese

\section{REFERENCES}

Alves, S. A. O. Regaste de híbridos interespecíficos de dendezeiro (Elaeis oleifera $\mathrm{x}$ Elaeis guineensis). Dissertação de Mestrado da Universidade Federal Rural da Amazônia/Museu Paráense Emilio Goeldi, Belém, Pará. 2007.

Alves, S. A. O.; Lemos, O. F. de; Santos Filho, B. G.; Silva, A. L. L. da. (2011), In vitro embryo rescue of interspecific hybrids of oil palm (Elaeis oleifera x Elaeis guineensis). Journal of Biotechnology and Biodiversity, 2, 1-6.

Amblard, P.; Noiret, J. M.; Kouame, B.; Potier, F.; Adon, B. (1995), Performances compares des Hybrides interespecifics et du materiel commercial E. guineensis. Oleagineux, Crops Gras et Lipides, Montepellier, 2, 335-340.

Cattelan, L. V.; Stein, V. C.; Souza, S. A.; Heiden, G.; Buttow, M. V.; Bobrowski, V. L. (2007), Estabelecimento in vitro de Matricaria recutita utilizando diferentes condições de cultivo. Revista Brasileira de Biociências, 5, 201-203. 
Cavalcante, A. S. L. Respostas morfogenéticas in vitro de açaizeiro (Euterpe oleracea L.) e de cupuçuazeiro (Theobrama grandiflorum (Wild. Ex Spreng) Schum). Tese de Doutorado da Universidade Federal do Ceará, 2001.

Cruz, C. D.; Regazzi, A. J. (2001), Modelos biométricos aplicados ao melhoramento genético. 2. ed. Viçosa: Universidade Federal de Viçosa, 390p.

Freitas, R. M. O. de; Oliveira, M. K. T. de; Dombroski, J. L. D.; Câmara, F. A. A. (2009), Efeito dos tratamentos de oxidação em Aloysia virgata. Revista Caatinga, 22, 151-154.

Hardon, J. J.; Tan, G. Y. (1969), Interespecific Hybrids in the Elaeis I. Crossability, cytogenetics and fertility of F1 Hybrids of E. guineensis $x E$. oleifera. Euphytica, 18, 372-379.

Murashige, T. and Skoog, F. (1962), Revised medium for rapid growth and bioassays with tobacco tissue culture. Physiologia Plantarum, 15, 473-497.

Nogueira, R. C.; Paiva, R.; Oliveira, L. M. S.; Araújo, G.; Soares, F. P.; Castro, A. H. F.; Paiva, P. D. O. (2007), Indução de calos em explantes foliares de murici-pequeno. Ciência $e$ Agrotecnologia, 31, 366-370.

Obisesan, O. and Fatunla, T. (1983), Genotype X environment interaction for bunch yield and its components in the oil palm (Elaeis guineensis Jacq.). Theoretical and applied Genetics, 64, 133136.
Pereira, J. E. S.; Maciel, T. M. S.; Costa, F. H. S.; Pereira, M. A. A. (2006), Germinação in vitro de embriões zigóticos de murmuru (Astrocaryum ulei). Ciência e Agrotecnologia, 30, 251-256.

Pullman, G. S.; Gupta, P. K.; Timmis, R.; Carpenter, C.; Kreitinger, M.; Welty, E. (2005), Improved Norway spruce somatic embryo development through the use of abscisic acid combined with activated carbon. Plant Cell Reports, 24, 271- 279.

Rajesh, M. K.; Radha, E.; Karun, A.; Parthasarathy, V. A. (2003), Plant regeneration from embryo-derived callus of oil palm - the effect of exogenous polyamines. Plant Cell, Tissue and Organ Culture, 75, 41-47.

Santos, M. R. A.; Ferreira, M. G. R.; Correia, A. O.; Rocha, J. F. (2010), In vitro establishment and callogenesis in shoot tips of peach palm. Revista Caatinga, 23, 40-44.

Souza, R. S.; Carvalho, S. M. L.; Garcia Junior, M. R. L.; Sena, R. S. F. (2009), Adsorção de cromo (VI) por carvão ativado granular de soluções diluídas utilizando um sistema batelada sob pH controlado. Revista Acta Amazônica, 39, 661-668.

Teixeira, J. B.; Söndahl, M. R.; Kirby, E. G. (1993), Somatic embryogenesis from immature zygotic embryos of oil palm. Plant Cell Tissue and Organ Culture, 34, 227-233.

Viegas, I. de J. M.; Muller, A. A. (2000), A cultura do dendezeiro na Amazônia brasileira. Belém: Embrapa-Cpatu; Manaus: Embrapa-CPAA, 374p. 